International Research Journal of Management, IT \& Social Sciences
Available online at https://sloap.org/journals/index.php/irjmis/
Vol. 7 No. 6, November 2020, pages: 9-20
$\begin{aligned} & \text { ISSN: 2395-7492 } \\ & \text { https://doi.org/10.21744/irjmis.v7n6.996 }\end{aligned}$

\title{
Information Technology Duty, Satisfaction and AIS Effectiveness Moderate Effect of Benefits of Informs Technology on Employee Performance
}

Ida Bagus Putra Astika AANB Dwirandra ${ }^{b}$

Article history:

Submitted: 9 July 2020

Revised: 18 August 2020

Accepted: 27 September 2020

\section{Keywords:}

AIS effectiveness;

AIS satisfaction;

employee performance;

IT utilization;

IT-task suitability;

\begin{abstract}
The purpose of this study was to determine the effect of IT benefits on employee performance. The specific objective of this study was to determine the effect of moderation in IT-task suitability, satisfaction, and effectiveness of AIS on the effect of IT usefulness on employee performance. The study population and using a purposive sampling method to determine the research sample. Furthermore, primary data was collected using a modified questionnaire from previous researchers and tested the validity and reliability of the instrument. Then, the collected data is tabulated and analyzed using MRA analysis techniques, through the following stages: 1) classical assumption test for compliance with the Best Linear Unbiased Estimator (BLUE) requirements which include: normality test, heteroscedasticity test, and multicollinearity test, 2) model feasibility test (F test), 3) analysis of the coefficient of determination (Adj. R2), and 4) hypothesis testing (t-test). The results showed that the usefulness of IT had a significant positive effect on employee performance. IT-task suitability, AIS satisfaction, and AIS effectiveness reinforce the positive influence of AIS benefits on employee performance.
\end{abstract}

International research journal of management, IT and social sciences (C) 2020. This is an open access article under the CC BY-NC-ND license (https://creativecommons.org/licenses/by-nc-nd/4.0/).

\section{Corresponding author:}

Ida Bagus Putra Astika,

Economics and Business Faculty, Udayana University, Denpasar, Indonesia.

Email address: astikaputra18@gmail.com

\footnotetext{
Economics and Business Faculty, Udayana University, Denpasar, Indonesia

Economics and Business Faculty, Udayana University, Denpasar, Indonesia
} 


\section{Introduction}

The Accounting Information System (AIS) is a system that provides accounting and financial information along with other information obtained from routine financial transaction processes (Hall, 2009). The implementation of AIS does not necessarily provide maximum benefits for the company. There are components involved in the use of accounting information systems in an organization, including the human component as actors who use the system (Romney \& Steinbart, 2014). Research by Gupta et al. (2008) found that the application of technology-based information systems in an organization can significantly increase profits and have a positive impact on organizational performance, and vice versa if the implementation of AIS is not optimal, the performance will not be optimal.

To date, there are 136 BPRs registered and operating in the Province of Bali, and 51 of them operate in Badung Regency, which is the largest number of BPRs in a district/city in Bali Province (Dwitrayani et al., 2017). Based on Table 1, it can be seen that BPR in Badung Regency has an average credit of 1,778,351,138 rupiahs and average growth of $18.4 \%$. However, the growth in the percentage of credit from 2012-2016 that occurred in rural banks in the Badung Regency showed a fluctuating growth that tended to decline. The lack of optimal BPR performance is thought to be inseparable from the performance of employees and/or supporting infrastructure, which may be triggered by employees' mastery of AIS and/or lack of information technology / IT support in supporting accountability, ease, accuracy, and speed of service.

Table 1

Credit Growth of BPR / BPRS in Badung Regency 2012-2016

\begin{tabular}{lll}
\hline Year & Total Credit (Thousands IDR) & Growth $(\%)$ \\
\hline 2012 & $1,265,854,283$ & 29 \\
2013 & $1,499,432,658$ & 18 \\
2014 & $1,809,455,548$ & 21 \\
2015 & $2,048,751,808$ & 13 \\
2016 & $2,268,261,394$ & 11 \\
Average & $1,778,351,138$ & 18.4 \\
\hline
\end{tabular}

(Source: OJK Bali and Nusa Tenggara, 2017)

The concept of TAM (Technology Acceptance Model) explains that a person's intention to use a system or technology is determined by two factors, namely the perception of IT usefulness (perceived usefulness), which is the level of individual believes that the use of technology will improve performance, and perceived ease of use is the individual's level of belief that the use of technology makes it easier to complete the job (Venkatesh \& Davis, 2000). Jackson et al. (1997), argue that the perceived benefits of IT will be able to support someone to make decisions that are beneficial to the organization or company. However, this does not necessarily happen because there are antecedent factors that need to be managed, such as: facilitating conditions and computer anxiety (Pauli et al., 2007). If someone/employee feels the precondition is not adequate and excessive anxiety that the benefits of IT will not be felt to sustain performance.

Several researchers have tested the effect of IT usefulness on employee / individual performance, such as Sagung (2008), shows that utilization Information technology has a positive and significant effect on performance individually, Kasandra (2014) found that IT benefits had a positive effect on individual performance, Astuti \& Dharmadiaksa (2014), revealed that IT benefits had a significant positive effect on employee performance in savings and loan cooperatives in Gianyar Regency. Meanwhile, several other researchers found different results, such as Jin (2003); Prapto (2010); Santosa (2013); and Retriana (2013), who stated that IT benefits do not affect employee performance.

Exposure to several previous studies related to the effect of IT benefits on employee performance shows inconsistent results. Govindarajan (1986), emphasized that there may not be any unified research results depending on certain factors or better known as contingency factors. Murray (1990), explains that to reconcile conflicting results, a contingency approach is needed to identify other variables that act as moderators or mediators in the research model. This study, with the various rationale for which it will be adjusted, intends to confirm the ability of IT-task suitability, AIS satisfaction, and AIS effectiveness, to moderate the effect of IT usefulness on employee performance. IT-task conformity.

Thompson (1995), states that task compatibility with information technology will lead individuals to achieve better performance. Rahmawati (2008), explains that IT-task suitability is related to the extent to which the individual's ability 
to use information technology in carrying out tasks to improve individual performance. Hamzah (2009), explains that task requirements, individual capabilities, and information system technology functions are an integral part that cannot be separated so that individual performance can be optimal. Several researchers, such as Akbar et al. (2010), Susilawati \& Sunarti (2011); Salamah (2012); Astuti (2014), found that IT-task suitability has a positive effect on employee performance. It is clear from this explanation that IT-task suitability improves individual performance. However, whether this variable moderates the effect of IT usefulness on employee performance needs to be confirmed as will be done through this study (Bedarkar \& Pandita, 2014; Van Dolen et al., 2004; Walumbwa et al., 2011; Kawiana et al., 2018).

The contingency factor of AIS satisfaction is closely related to the way users perceive information systems in real terms and information system user satisfaction with the accounting software used and the output produced by the software (Guimaraes et al., 2007 and Istianingsih \& Setyo, 2008). Related research has been conducted, such as Iranto (2012); Istianingsih \& Utami (2009), and Raminda (2014), which found that AIS satisfaction has a positive effect on individual performance. Does this mean that the AIS satisfaction variable can moderate the effect of IT benefit on employee performance certainly needs to be confirmed as will be done in this study?

The contingency factor of the effectiveness of AIS is a measure of how well the work can be done and the extent to which a person can produce the expected outcomes (Kristiani, 2012). Fatmayoni \& Yadnyana (2017), emphasize that, based on the TAM theory, an employee as an AIS user can receive benefits and experience the convenience of having an accounting information system, so performance will certainly be facilitated by the existence of such a system. Related research has been conducted by Panggeso (2014) and Astuti (2014), who found that the effectiveness of accounting information systems has a positive and significant effect on employee and company performance. Thus, it is possible to have a moderating role in the influence of IT benefits on employee performance, although it must be confirmed first.

In contrast to research conducted by Iranto (2012), Istianingsih \& Utami (2009); Raminda (2014); Panggeso (2014); and Astuti (2014), this study tries to determine the moderation ability of three contingency factors. (IT-task suitability, AIS satisfaction, and AIS effectiveness) on the effect of IT usefulness on employee performance.

\section{Literature review}

The Theory of Technology Acceptance Model (TAM) and The Theory of Technology-to-Performance Chain (TPC)

TAM (Technology Acceptance Model) which was first introduced by Davis et al. (1989), is a type of theory that uses a behavioral theory approach which is widely used to study the process of information technology adoption and explains that the use of information systems will be influenced by variables. usefulness and ease of use variables. TAM is assumed that the use of the system is determined by the intentions of user behavior in using the system. The TAM model is adopted from the Theory of Reasoned Action (TRA) model which explains that computer use is determined by individual attitudes towards system use and feelings of usefulness (Hamner, 2009; Yang et al., 2006).

The Technology-to-Performance Chain (TPC) model is a comprehensive model built from two complementary research streams, namely the user attitude as a predictor of utilization and the suitability of technology tasks ( tasktechnology fit) as a predictor of performance (Jogiyanto, 2007). The essence of this model is for information technology to have a positive impact on individual performance, the technology must be utilized and the technology must be by the type of work being performed (Agustiani, 2010).

The technology-to-performance chain model is built by combining the utilization model with the fit model. The TPC chain model is a model in which technology will result in performance impacts if used by individuals. Recognizing that technology must be utilized first and fit the tasks supported by the technology to have a performance impact, this model provides a more accurate picture of technology, user tasks, and utilization are interconnected to achieve performance.

\section{Hypothesis \\ Utilization of IT and its influence on Employee Performance}

Davis et al. (1989) and Adam et al. (1992), define IT usefulness as a level of one's perception of believing that the use of a particular subject will be able to increase the person's work performance. Furthermore, Thompson et al. (1991), explained that IT benefits are the benefits expected by IT users in carrying out their duties. Hamzah (2009), states that the perception of IT benefits is related to data processing, information processing, management systems, and work processes electronically.

Astika, I. B. P. ., \& Dwirandra, A. . (2020). Information technology duty, satisfaction and ais effectiveness moderate effect of benefits of informs technology on employee performance. International Research Journal of Management, IT and Social Sciences, 7(6), 9-20. https://doi.org/10.21744/irjmis.v7n6.996 
Brian \& Sawyer (2007), define technology as a general form that describes any technology that helps generate, manipulate, store, communicate, and or convey information. Wuryaningrum (2007), suggests that information technology implemented in organizations should be able to provide benefits to individual and organizational performance and provide comfort for the wearer. Making decisions that are more effective and informative, system development needs to have a better understanding of the factors that influence the use of information technology.

Research conducted by Prebawa (2012), found that the use of information technology has a positive effect on employee performance. The number of computers in a company greatly affects IT implementation. Several other researchers, such as Utari (2012) and Astuti (2014), found that IT benefits increase the impact of employee performance. Based on the conception and empirical research that has been described, it can be seen that the usefulness of IT has a positive effect on employee performance. The more you feel the benefits of the existence of IT, the stronger the incentive for employees to use IT to achieve optimal performance. Thus the following research hypothesis can be developed:

H1: Utilization of IT has a positive effect on employee performance.

\section{IT-task suitability and its ability to moderate the effect of IT usefulness on employee performance}

The relevance of information technology or the suitability of tasks with information technology plays a major role in improving employee performance because it is directly related to the use of technology in carrying out existing tasks. The suitability of tasks with information technology more specifically shows the relationship between IT use and task requirements (Siregar \& Suryanawa, 2009). According to Astuti (2014), the suitability of tasks with IT is the suitability of applied information technology with the characteristics of the duties and abilities of employees, to improve employee performance. The application of technology in company information systems should consider the use of the technology system applied so that it can be utilized according to the duties and abilities of employees, it is not uncommon to find that the technology applied in information systems is often incorrect or not fully utilized by employees so that information systems provide less benefit in improving employee performance (Sugiantara, 2017).

Innovation will be preferred if it is by the individual job responsibilities (Jin, 2003). Salamah (2012), explain that task requirements must be by individual capabilities supported by information system technology functions. According to Weyai (2012), the suitability of tasks with technology is the level where individuals are greatly assisted by technology in carrying out their duties and responsibilities. With the help of technology, it is hoped that individuals can complete various tasks with relevance, which can later be useful in the resulting performance. Goodhue and Thompson (1995), found that the suitability of technology tasks will lead individuals to achieve better performance. Based on theoretical and conceptual descriptions and empirical research, it can be seen that the effectiveness of AIS has a positive effect on employee performance. Thus, it should be assumed that the higher the effectiveness of AIS will increase the effect of IT benefits on employee performance. Thus, the following research hypothesis can be developed:

H2: IT-task suitability reinforces the positive influence of IT usefulness on employee performance.

\section{AIS satisfaction and its ability to moderate the influence of IT Usefulness on Employee Performance}

Davis et al. (1989), says that the impact of using an information system on individual users (individual impact) is defined as the degree to which a person believes that using a particular system can improve their performance. Meanwhile, Seddon (1997), defines this individual performance as the user's opinion on a specific application system. Which is used in improving their performance within the organization.

User satisfaction with an information system is how users perceive the information system in real terms, but not on the quality of the system technically (Guimaraes et al., 2003). In the research literature and practice, user satisfaction is often used as a surrogate measure of the effectiveness of information systems (Melone, 1990). Doll \&Torkzadeh (1988), define end-user satisfaction as an "affective attitude towards a specific computer application by someone who interacts with the application directly." Istianingsih \& Setyo (2008), explain that information system user satisfaction is the level of user satisfaction with the accounting software used and the output produced by the software. Satisfaction can be said as a behavior where a user can use the available system repeatedly because they have felt the benefits and obtained satisfaction from the system. Some researchers, such as McLean (1989); Seddon (1997); Rai et al., (2002); Livari (2005); Dekeng \& Dessy (2015); Raminda (2014); Kurniawati et al. (2017), found that information system user satisfaction affects the quality of an individual or employee performance. Based on the conception description and empirical research above, it can be seen that AIS satisfaction has a positive effect on employee performance, or in 
other words, employees who feel satisfaction at a high AIS will improve their performance. Furthermore, if an employee feels AIS satisfaction, he will likely be able to encourage the benefits of IT to further optimize performance. With such a logical framework, the following research hypothesis can be developed:

H3: AIS satisfaction reinforces the positive influence of IT Use on Employee Performance.

\section{The effectiveness of AIS and its ability to moderate the influence of IT Usefulness on employee performance}

Effectiveness, which comes from the word effective, is the achievement of the right goal by making the right choice from a series of alternatives for making a decision, while effectiveness has the meaning of being successful or effective in achieving the stated goals (Antasari, 2015). In general, an effective system is defined as a system that can provide added value to the company, so that each system is required to have a positive influence on its users. The effectiveness of the use and implementation of information systems technology in the company can be seen from the way users identify data, access data, and interpret the data (Jumaili, 2005). Utomo (2013), emphasizes that business processes and decision making will be even better if the company implements information technology properly and correctly so that a good internal control process is needed for information technology applications in the company. Furthermore, Sajady et al. (2012), emphasized that the effectiveness of the system is based on its contribution to decision making, the quality of accounting information, performance evaluation, internal control that facilitates corporate transactions.

Several researchers have conducted related research, such as Awesejo et al. (2013); Astuti \& Dharmadiaksa (2014); Suratini et al. (2015); Mercika \& Jati (2015); Ambara (2016); Fatmayoni \& Yadnyana (2017), and found that the effectiveness of AIS has a positive effect on individual/employee performance. Based on the conception and empirical research results that have been described, it can be seen that the effectiveness of AIS has a positive effect on employee performance, or in other words, the more effective the AIS, the more employee performance will be increased. Furthermore, if an employee feels the effectiveness of the implemented AIS is high, it may increase employees' perceptions of the useful role of IT to optimize their performance. Thus, based on the logical framework that has been described, the following research hypothesis can be developed:

H4: The effectiveness of AIS strengthens the positive influence of IT benefits on employee performance.

\section{Materials and Methods}

This research was conducted at a BPR located in Badung Regency. The choice of BPR in Badung Regency as the research location is because Badung Regency is a district that has a superior tourism sector in Bali with the highest level of Regional Original Income in Bali. Badung Regency also has the largest number of BPRs compared to other districts in Bali based on data obtained from Perbarindo. The object of this research is about the usefulness of IT, suitability of IT-tasks, AIS satisfaction, the effectiveness of AIS on the performance of BPR employees in Badung Regency. The population in this study were employees of information technology users and / or accounting information systems at BPRs in Badung regency. While the sampling technique in this study used purposive sampling, namely the sampling technique with certain considerations. The criteria for determining the sample used in this study are 1) the head of accounting and the accounting department, 2) employees who have used information technology and / or accounting information systems for $\geq 2$ years.

\section{Results and Discussions}

\section{Descriptive analysis}

Descriptive statistics in this study were tested to provide information about the characteristics of the research variables. The minimum value indicates the smallest or lowest value in a data set. The maximum value indicates the largest or highest value in a data set. The average (mean) is the most AIS common way to measure the central value of a data distribution under study. Standard deviation is a measure that shows the standard deviation of the observed data from the average data (Ghozali, 2017).

Astika , I. B. P. ., \& Dwirandra , A. . (2020). Information technology duty, satisfaction and ais effectiveness moderate effect of benefits of informs technology on employee performance. International Research Journal of Management, IT and Social Sciences, 7(6), 9-20. https://doi.org/10.21744/irjmis.v7n6.996 
Table 2

Statistic Descriptive

\begin{tabular}{lllll}
\hline \multicolumn{1}{c}{ Variabel } & Min & Maks & Mean & Std. Deviation \\
\hline Use of Information Technology (KEM) & 2,00 & 4,00 & 3,2787 & 0,56828 \\
Task Fit - IT (KES) & 2,00 & 4,00 & 3,3327 & 0,56305 \\
Accounting Information System Satisfaction (KEP) & 2,00 & 4,00 & 3,4337 & 0,66337 \\
Effectiveness of Accounting Information Systems (EFE) & 2,00 & 4,00 & 3,3941 & 0,60429 \\
Employee performance (KIN) & 2,00 & 4,00 & 3,4099 & 0,61147 \\
\hline Valid N (listwise) & 101 & & &
\end{tabular}

Source: Data processed, 2018

\section{Hypothesis test}

The research instrument used in this study has tested the validity and reliability test, where the results of the validity test show that the Pearson correlation value of each respondent's statement is greater than 0.30. This means that all respondents' statements in the questionnaire have met the valid requirements so that they are suitable for use in research. Meanwhile, the reliability test results show that all research instruments, namely the Use of Information Technology, Information Technology Relevance, Accounting Information System Satisfaction, Accounting Information System Effectiveness, and Employee Performance, have a Cronbach's Alpha coefficient greater than 0.70 so that it can be said to be reliable and worthy of use in research. This means that if the measurement is carried out more than once for the same symptom, the measurement will give consistent results.

Before doing multiple linear regression analysis, the regression model that is made must go through the classical assumption test first so that the resulting equation meets the BLUE (Best, Linear, Unbias, Estimator) rules. From the results of the normality test, it can be seen that the coefficient value of Asymp.Sig. (2-tailed) is 0.066 greater than the alpha value of 0.05. This shows that the variables KEM, KES, KEP, EFE, and KIN are normally distributed.

The multicollinearity test results show that all independent variables in this study, namely the use of information technology, the relevance of information technology, the satisfaction of accounting information systems, the effectiveness of accounting information systems show a tolerance value greater than 0.10 and VIF less than 10 . This indicates that the model of the regression equation shows no multicollinearity symptoms between independent variables. While the results of the heteroskedastic test showed that all independent variables in this study, namely IT usefulness, IT suitability, AIS satisfaction, AIS effectiveness, showed sig values each of 0.792;0.260;0.806; and 0.231 which is greater than 0.05 . This means that there is no influence between the independent variables on absolute residuals, so the regression model used does not contain heteroscedasticity symptoms.

The results of the t-test for the MRA model to test the effect of the independent variables and the moderating variables of the study are presented in Table 3 as follows.

Table 3

MRA test result

\begin{tabular}{|c|c|c|c|c|c|c|}
\hline & \multirow[t]{2}{*}{ Model } & \multicolumn{2}{|c|}{$\begin{array}{c}\text { Unstandardized } \\
\text { Coefficients }\end{array}$} & \multirow{2}{*}{$\begin{array}{c}\begin{array}{c}\text { Standardized } \\
\text { Coefficients }\end{array} \\
\text { Beta } \\
\end{array}$} & \multirow[t]{2}{*}{ Sig. } & \multirow{2}{*}{$\begin{array}{l}\text { Hypotheses test } \\
\text { result }\end{array}$} \\
\hline & & $\mathrm{B}$ & Std. Error & & & \\
\hline \multirow[t]{8}{*}{1} & (Constant) & .628 & 4.313 & & .008 & \\
\hline & KEM & .192 & .249 & .214 & .004 & $\mathrm{H}_{1}$ accepted \\
\hline & KES & 1.110 & .412 & 1.022 & .000 & - \\
\hline & KEP & .141 & .429 & .153 & .007 & - \\
\hline & EFE & .546 & .383 & .539 & .001 & - \\
\hline & KES.KEM & .049 & .022 & 1.557 & .000 & $\mathrm{H}_{2}$ accepted \\
\hline & KEP.KEM & .002 & .023 & .055 & .009 & $\mathrm{H}_{3}$ accepted \\
\hline & EFE.KEM & .049 & .021 & 1.652 & .000 & $\mathrm{H}_{4}$ accepted \\
\hline
\end{tabular}

a. Dependent Variable: KIN 
To reveal the effect of independent variables and moderating variables using the MRA technique. The regression test results related to the effect of KEM on KIN obtained the Sig. of 0.004 with a beta coefficient of 0.192 , which means that the IT benefit variable has a positive and significant effect on employee performance. Or, in other words, the perceived usefulness of IT in supporting the implementation of its duties will further improve the performance of BPR accounting employees in the Badung Regency. These results fail to reject H1 which states that IT usability has a positive and significant effect on employee performance.

The regression test results related to the effect of KES on KIN obtained the Sig. of 0.000 with a beta coefficient of 1.110, which means that the IT-task suitability variable has a positive and significant effect on employee performance. Or, in other words, the higher IT conformity with the tasks that must be completed by BPR accounting employees in Badung Regency in supporting the implementation of their duties will further improve their performance.

The regression test results related to the effect of KEP on KIN obtained the Sig. of 0.007 with a beta coefficient of 1.41, which means that the AIS satisfaction variable has a positive and significant effect on employee performance. Or, in other words, the higher the satisfaction of BPR accounting employees in Badung Regency with AIS, the more they will improve their performance.

The regression test results related to the effect of KES on KIN obtained the Sig. of 0.001 with a beta coefficient of 0.546, which means the effectiveness of the AIS variable has a positive and significant effect on employee performance. Or, in other words, the more effective AIS will be in helping to solve the process and presentation of information problems that must be resolved by BPR accounting employees in the Badung Regency will further improve their performance.

The results of the MRA test related to moderation of IT-task suitability to the positive influence of IT benefits on employee performance obtained the Sig. of 0.000 with a beta coefficient of 0.049 , which means that the IT-task suitability variable strengthens the positive influence of IT effectiveness on employee performance. Or, in other words, the positive contribution of IT benefits to the performance of BPR accounting employees in the Badung Regency will increase if IT is felt to be by the tasks that must be completed. These results fail to reject the $\mathrm{H} 2$ hypothesis which states that IT-task suitability strengthens the positive influence of IT utility on employee performance.

The results of the MRA test related to the moderation of AIS satisfaction on the positive influence of IT benefits on employee performance obtained the Sig. of 0.009 with a beta coefficient of 0.002 , which means that the AIS satisfaction variable increases the positive effect of IT usefulness on employee performance. Or, in other words, the acceleration of IT benefit support in improving employee performance occurs when accounting employees of BPR in Badung Regency feel the compatibility of TO with efforts to complete their tasks. These results fail to reject $\mathrm{H} 2 \mathrm{which}$ states that AIS satisfaction (KEP) strengthens the positive effect of IT benefit (KEM) on employee performance (KIN).

Based on Table 2, it can be seen that the standardized coefficient beta of the influence of the KES.KEM variable is 1.557 with a sig value. 0.000, KEP.KEM is 0.055 with a sig. 0.009, and EFE.EM of 1.652 with a sig. 0.00 . Based on these data it can be said that the three contingency variables, namely: IT-task suitability, AIS satisfaction, and AIS effectiveness have a positive effect on employee performance. The most dominant moderation ability, respectively, is the AIS effectiveness variable which has the highest beta coefficient value (1652), then the IT-task suitability variable, and AIS satisfaction.

\section{Discussion}

\section{Utilization of IT has a positive and significant effect on employee performance}

The results of the study reveal that IT benefits have a positive and significant effect on employee performance. In other words, the more beneficial IT is felt by employees, the more enthusiastic they will be in using IT and the morale will increase so that it will lead to better performance. The main indicator of the benefits of IT that is most prominent and contributes positively is related to the support of superiors to introduce IT benefits, while the most important thing is to increase efforts to make IT more attractive and easier, and its role is real in shortening work time.

The results of this study are by the findings of previous studies conducted by Sagung (2008), showing that utilization Information technology has a positive and significant effect on individual performance, Kasandra (2014), finds that IT benefits have a positive effect on individual performance, Marlita \& Dharmadiaksa (2014) reveal that IT benefits have a significant positive effect on employee performance in savings and loan cooperatives in Gianyar Regency. Meanwhile, several other researchers found different results, such as Jin (2003); Prapto (2010); Santosa (2013); and Retriana (2013), who stated that IT benefits did not affect employee performance.

Astika , I. B. P. ., \& Dwirandra , A. . (2020). Information technology duty, satisfaction and ais effectiveness moderate effect of benefits of informs technology on employee performance. International Research Journal of Management, IT and Social Sciences, 7(6), 9-20. https://doi.org/10.21744/irjmis.v7n6.996 


\section{IT-Task Suitability strengthens the positive influence of IT Utilization on Employee Performance}

The results of this study found that IT-task suitability strengthens the positive influence of IT utility on employee performance. This means that the positive contribution of IT benefits to improving employee performance will be even higher if there is IT compatibility with the tasks that must be completed by employees.

The main indicator of IT utilization, which is the most prominent and has a positive contribution, is related to the maintenance and provision of detailed data to meet task needs, which relatively received more appreciation from respondents. Meanwhile, what is still more necessary to get attention is related to the role of computers in facilitating system operation.

Furthermore, it can be informed that in addition to evidence of the moderating role of IT-task suitability, it is also revealed that there is a partial effect of IT-task suitability on employee performance. Thus, based on the classification of the moderating variables from Solimun (2002), the IT-task suitability variable is a quasi-moderator type. The results of this study are by the results of research by Rahmawati (2008), who found that task-technology suitability has a positive effect on individual performance. The results of research conducted by Astuti (2014) and Sugiantara \& Dwiana (2017) state that task suitability with information technology has a positive effect on individual performance.

\section{AIS satisfaction strengthens the influence of IT Usefulness on Employee Performance}

Accounting information system user satisfaction is the user's response to the performance produced by the accounting information system to meet their needs. Do users feel like the information system is used because it is by their expectations and makes it easier for users to complete their tasks related to information systems so that users can feel satisfied (Raminda \& Ardini, 2014).

The results of this study reveal that AIS satisfaction strengthens the positive influence of IT benefits on employee performance. This means that the role of IT benefits in efforts to improve employee performance is higher if employees are satisfied with AIS. Furthermore, it can be informed that in addition to the moderating role of AIS satisfaction, it is also found evidence that partially the AIS satisfaction variable has a positive effect on employee performance. Thus, based on the classification of the moderating variables from Solimun (2002), the AIS satisfaction variable is the quasimoderator type.

Furthermore, it can be informed that the main indicator of the AIS satisfaction variable that stands out the most compared to other indicators and contributes positively to improving employee performance is related to the convenience provided by AIS. Meanwhile, the indicators that most need attention for immediate improvement are related to the understanding or interpretation of the information presented by the AIS, as well as the ease of application of AIS in completing work.

The results of this study are consistent with the findings of research conducted by McLean (1989); Seddon (1997); Rai et al. (2002); Livari (2005); Dekeng \& Dessy (2015); Raminda (2014); Kurniawati et al. (2017), who found that information system user satisfaction affects the quality of an individual or employee performance.

\section{The effectiveness of AIS strengthens the influence of IT Usefulness on Employee Performance}

Accounting information systems are very influential in supporting company productivity. Because it is believed that the existence of an accounting information system allows companies to carry out operational and information processes more effectively and efficiently so that the results achieved can be by company objectives. The results of this study found that the effectiveness of AIS strengthens the effect of IT usefulness on employee performance. Or in other words, the role of IT usefulness in improving employee performance is getting higher with the effectiveness of AIS in resolving data processing and presentation problems.

It has been previously explained that this research found a moderating role for the effectiveness of AIS and empirical evidence that partially the AIS effectiveness variable has a positive effect on employee performance. Thus, based on the classification of the moderating variables from Solimun (2002), the AIS effectiveness variable is classified as a quasi-moderator type.

Also, it can be informed that the main indicator of the AIS effectiveness variable that stands out the most compared to other indicators and contributes positively to improving employee performance is the relatively short time it takes to present information with the presence of IT. Meanwhile, the indicators that most need attention to be addressed are related to back-up as a backup or a substitute for data security in anticipation of fire or other natural disasters. 
Then, it can also be informed that the findings of this research are in line with the findings of several previous researchers, such as Awesejo et al. (2013); Astuti \& Dharmadiaksa (2014); Suratini et al. (2015); Mercika \& Jati (2015); Hendriana \& Hendriana \& Ambara (2016) ); Fatmayoni \& Yadnyana (2017), and found that the effectiveness of AIS has a positive effect on individual/employee performance.

\section{Conclusion}

Based on the discussion that has been done in the previous chapter, it can be concluded as follows:

1) IT benefits to improve employee performance.

2) The suitability of IT-tasks strengthens the influence of IT benefits on improving employee performance.

3) AIS satisfaction strengthens the influence of IT benefits on improving employee performance.

4) The effectiveness of AIS does not strengthen the effect of IT benefits on improving employee performance.

Conflict of interest statement

The authors declared that they have no competing interests.

Statement of authorship

The authors have a responsibility for the conception and design of the study. The authors have approved the final article.

\section{Acknowledgments}

We are grateful to two anonymous reviewers for their valuable comments on the earlier version of this paper.

Astika , I. B. P. ., \& Dwirandra, A. . (2020). Information technology duty, satisfaction and ais effectiveness moderate effect of benefits of informs technology on employee performance. International Research Journal of Management,

IT and Social Sciences, 7(6), 9-20. https://doi.org/10.21744/irjmis.v7n6.996 


\section{References}

Adams, D. A., Nelson, R. R., \& Todd, P. A. (1992). Perceived usefulness, ease of use, and usage of information technology: A replication. MIS quarterly, 227-247.

Agustiani, N. H. (2010). Pengaruh pemanfaatan sistem informasi akademik terpadu (sikadu) terhadap Kinerja individual dengan kemudahan penggunaan sebagai variabel moderating (studi empiris pada fakultas teknik Universitas Negeri Semarang) (Doctoral dissertation, Universitas Diponegoro).

Akbar, N., Ratnawati, V., \& Novita, V. (2010). Pengaruh pengetahuan teknologi informasi, pemanfaatan teknologi informasi, dan faktor kesesuaian tugas-teknologi terhadap kinerja akuntan internal. Jurnal Ekonomi, 18(02).

Antasari, K. C., Sukartha, P. D. Y. Y., \& D'yan, P. (2015). Pengaruh Efektivitas Sistem Informasi Akuntansi Dan Penggunaan Teknologi Informasi Pada Kinerja Individual Dengan Kepuasan Kerja Sebagai Variabel Pemoderasi. E-Jurnal Akuntansi Universitas Udayana, 10(2), 354-369.

Astuti, N. M. M. (2014). Pengaruh Efektivitas Penerapan Sistem Informasi Akuntasi, Pemanfaatan dan Kesesuaian Tugas dengan Teknologi Informasi terhadap Kinerja Karyawan pada Koperasi Simpan Pinjam di Kabupaten Gianyar. Skripsi Jurusan Akuntansi Fakultas Ekonomi Universitas Udayana.

Astuti, N. M. M. P., \& Dharmadiaksa, I. B. (2014). Pengaruh Efektivitas Penerapan Sistem Informasi Akuntansi, Pemanfaatan dan Kesesuaian Tugas pada Kinerja Karyawan. E-Jurnal Akuntansi Universitas Udayana, 9(2), 373384.

Awesejo, O.J., Kekwaletswe, R, M., Pretorius, P \& Zuva, T. (2013). The Effect of Accounting Information Systems in Accounting. 3(1), 142-150.

Bedarkar, M., \& Pandita, D. (2014). A study on the drivers of employee engagement impacting employee performance. Procedia-Social and Behavioral Sciences, $133, \quad 106-115$. https://doi.org/10.1016/j.sbspro.2014.04.174

Davis, F. D., Bagozzi, R. P., \& Warshaw, P. R. (1989). User acceptance of computer technology: a comparison of two theoretical models. Management science, 35(8), 982-1003.

Dekeng, S., \& Dessy, A. R. (2015). Pengaruh Kualitas Informasi Dan Kualitas Sistem Informasi Terhadap Kepuasan Serta Kinerja Pengguna Sistem Informasi. Efektif Jurnal Bisnis dan Ekonomi 6(1), 47-59.

Doll, W. J., \& Torkzadeh, G. (1988). The measurement of end-user computing satisfaction. MIS quarterly, $259-274$.

Dwitrayani, M. C., Widanaputra, A. A. G. P., \& Putri, I. G. A. M. A. D. (2017). Pengaruh kecanggihan teknologi informasi, partisipasi manajemen, budaya organisasi dan kepuasan pengguna pada efektivitas sistem informasi akuntansi Bank Perkreditan Rakyat di Kabupaten Badung. E-Jurnal Ekonomi Dan Bisnis Universitas Udayana, 1, 197-222.

Fatmayoni, I. G. A. A. I., \& Yadnyana, I. K. (2017). Pengaruh Efektivitas Sia dan Penggunaan Teknologi Informasi pada Kinerja Individual dengan Insentif Karyawan Sebagai Pemoderasi. E-Jurnal Akuntansi Fakultas Ekonomi dan Bisnis Universitas Udayana, 19.

Ghozali, I. (2017). Econometrics Theory, Concepts, and Applications with SPSS 17. Semarang: Diponegoro University Publishing Agency.

Goodhue, D. L., \& Thompson, R. L. (1995). Task-technology fit and individual performance. MIS quarterly, $213-236$.

Govindarajan, V. (1986). Impact of participation in the budgetary process on managerial attitudes and performance: Universalistic and contingency perspectives. Decision sciences, 17(4), 496-516.

Guimaraes, T., Staples, D. S., \& McKeen, J. (2007). Assessing the impact from information systems quality. Quality Management Journal, 14(1), 30-44.

Guimaraes, T., Staples, D. S., \& Mckeen, J. D. (2003). Empirically testing some main user-related factors for systems development quality. Quality Management Journal, 10(4), 39-50.

Hall, J. A. (2007). Sistem Informasi Akuntansi Edisi 4. D. Foriasari, \& DA Kwary, terj.). Jakarta: Penerbit Salemba Empat.

Hamner, M. (2009). Expanding the technology acceptance model to examine personal computing technology utilization in government agencies in developing countries. Government information quarterly, 26(1), 128-136. https://doi.org/10.1016/j.giq.2007.12.003

Hamzah, A. (2009). Evaluasi kesesuaian model keperilakuan dalam penggunaan Teknologi sistem informasi di indonesia. In Seminar Nasional Aplikasi Teknologi Informasi (SNATI).

Handriana, T., \& Ambara, R. (2016). Responsible environmental behavior intention of travelers on ecotourism sites. Tourism and hospitality management, 22(2), 135-150. 
Iranto, B. D., \& Januarti, I. (2012). Pengaruh kepuasan pengguna sistem informasi terhadap kinerja individu (Studi pada PT. PLN (PERSERO) Distribusi Jawa Tengah dan DIY) (Doctoral dissertation, Fakultas Ekonomika dan Bisnis).

Istianingsih dan Setyo Hari Wijanto. (2008). Pengaruh Kualitas Sistem informasi,Kualitas Informasi, dan Percived Usefulness Terhadap Kepuasan PenggunaSoftware Akuntansi. Simposium Nasional Akuntansi IX, Pontianak.

Istianingsih, I., \& Utami, W. (2009). Pengaruh Kepuasan Pengguna Sistem Informasi Terhadap Kinerja Individu. Simposium Nasional Akutansi XII, 1-70.

Jackson Chintya M., Simeon Chow \& Leitch Robert A. (1997). Toward Understanding the Behavioral Intention to Use an Information Sistem. Decision Sciences, 28(2), 357- 389.

Jin, T. F. (2003). Analisis faktor-faktor yang mempengaruhi pemanfaatan teknologi informasi dan pengaruh pemanfaatan teknologi informasi terhadap kinerja akuntan publik. Jurnal bisnis dan akuntansi, 5(1), 1-26.

Jogiyanto, H. M. (2007). Model Kesuksesan Sistem Teknologi Informasi. Yogyakarta: Penerbit Andi.

Jumaili, S. (2005). Kepercayaan terhadap teknologi sistem informasi baru dalam evaluasi kinerja individual. Solo: Simposium Nasional Akuntansi VIII.

Kasandra, N. M. A. A. (2014). Pengaruh Kualitas Penerapan Sistem Informasi Akuntansi, Pemanfaatan dan Kepercayaan Teknologi Informasi Terhadap Kinerja Karyawan pada Bank Perkreditan Rakyat di Kabupaten Tabanan. Skripsi. Jurusan Akuntansi Fakultas Ekonomi dan Bisnis Universitas Udayana.

Kawiana, I. G. P., Dewi, L. K. C., Martini, L. K. B., \& Suardana, I. B. R. (2018). The influence of organizational culture, employee satisfaction, personality, and organizational commitment towards employee performance. International research journal of management, IT and social sciences, 5(3), 35-45.

Kristiani, W. (2012). Analisis Pengaruh Efektivitas Teknologi Sistem Informasi Akuntansi Terhadap Kinerja Individual Pegawai Pt. Kim Eng Sekuritas Indonesia.

Kurniawati, A. A., Wahyuni, S., \& Putra, P. D. (2017). Utilizing of comic and jember's local wisdom as integrated science learning materials. International Journal of Social Science and Humanity, 7(1), 47.

Livari, J. (2005). An empirical test of the DeLone-McLean model of information system success. ACM SIGMIS Database: the DATABASE for Advances in Information Systems, 36(2), 8-27.

McLean, I. (1989). Democracy and new technology. Polity Press.

Melone, N. P. (1990). A theoretical assessment of the user-satisfaction construct in information systems research. Management science, 36(1), 76-91.

Mercika, N. L. D. Jati. 2015. Kemudahan Penggunaan Sistem Sebagai Pemoderasi Pengaruh Efektivitas Sistem Informasi Akuntansi Pada Kinerja, 723-737.

Murray, D. (1990). The performance effects of participative budgeting: An integration of intervening and moderating variables. Behavioral Research in accounting, 2(2), 104-123.

Panggeso, N. F. (2014). Efektivitas Penggunaan dan Kepercayaan atasSistem Informasi Akuntansi terhadap Kinerja Karyawan PT BankSulselbar di Makassar. SKRIPSI. Makasar: Fakultas Ekonomi danBisnis, Universitas Hasanuddin Makassar.

Pauli, K. P., Gilson, R. L., \& May, D. R. (2007). Anxiety and avoidance: The mediating effects of computer selfefficacy on computer anxiety and intention to use computers. Review of Business Information Systems (RBIS), 11(1), 57-64.

Prapto, S. (2010). Pengaruh pemanfaatan teknologi informasi, dan pengendalian intern akuntansi terhadap keterandalan dan ketepatwaktuan pelaporan keuangan Pemerintah Daerah (Studi pada Pemerintah Kabupaten Sragen) (Doctoral dissertation, UNS (Sebelas Maret University)).

Prebawa Manuaba, I. B. (2012). Pengaruh Efektivitas Penggunaan Teknologi Informasi, Kepercayaan Pemakai Teknologi Informasi dan Kesesuian Tugas Terhadap Kinerja Karyawan pada Koperasi Simpan Pinjam di Kecamatan Denpasar Timur. Skripsi Fakultas Ekonomi Universitas Udayana.

Rahmawati, D. (2008). Analisis Faktor Faktor yang Berpengaruh Terhadap Pemanfaatan Teknologi Informasi. Jurnal Ekonomi dan Pendidikan, 5(1).

Rai, A., Lang, S. S., \& Welker, R. B. (2002). Assessing the validity of IS success models: An empirical test and theoretical analysis. Information systems research, 13(1), 50-69.

Raminda, A. L. N., \& Ardini, L. (2014). Pengaruh Kualitas Sistem, Kualitas Informasi dan Kepuasan Pengguna Accurate terhadap Kinerja Individu. Jurnal Ilmu \& Riset Akuntansi, 3(9), 1-15.

Retriana, B. (2013). Pengaruh Pemanfaatan Teknologi Informasi terhadap Kinerja Individual pada Kantor Dinas Kependudukan dan Pencatatan Sipil Kabupaten Wonogiri (Doctoral dissertation, Universitas Muhammadiyah Surakarta).

Astika , I. B. P. ., \& Dwirandra, A. . (2020). Information technology duty, satisfaction and ais effectiveness moderate effect of benefits of informs technology on employee performance. International Research Journal of Management, IT and Social Sciences, 7(6), 9-20. https://doi.org/10.21744/irjmis.v7n6.996 
Romney, M. B., \& Steinbart, P. J. (2014). Sistem Informasi Akuntansi: Accounting Information Systems.

Sajady, H., Dastgir, M., \& Nejad, H. H. (2012). Evaluation of the effectiveness of accounting information systems. International Journal of Information Science and Management (IJISM), 6(2), 49-59.

Salamah, I. (2012). Pemanfaatan Sistem Informasi dan Teknologi Informasi Pengaruhnya Terhadap Kinerja Individual Karyawan. Jurnal Akuntansi dan Keuangan, 14(1), 56-68.

Santosa, D. A. (2013). Pengaruh Pemanfaatan Teknologi Informasi Terhadap Kinerja Individu Mahasiswa Program Pendidikan Strata Satu Jurusan Akuntansi Di STIE Perbanas Surabaya (Doctoral dissertation, STIE Perbanas Surabaya).

Seddon, P. B. (1997). A respecification and extension of the DeLone and McLean model of IS success. Information systems research, 8(3), 240-253.

Siregar, A. H., \& Suryanawa, I. K. (2009). Pemanfaatan Teknologi Informasi dan Pengaruhnya Pada Kinerja Individual Pada Kantor Pelayanan Pajak Pratama Denpasar Barat. E-Journal Akuntansi Universitas Udayana, 1-24.

Solimun, M. S. (2002). Structural Equation Modelling (SEM) Lisrel dan Amos. Malang: Fakultas MIPA Universitas Brawijaya.

Sugiantara, P. P. O., \& Putra, I. M. P. Dwiana. (2017). Analisis Faktor-Faktor Yang Mempengaruhi Kinerja Karyawan Di Dispenda Kota Denpasar. E-Jurnal Akuntansi Universitas Udayana 20(3).

Suratini, N. P. E., Sinarwati, N. K., Atmadja, A. T., \& SE, A. (2015). Pengaruh Efektivitas Sistem Informasi Akuntansi dan Penggunaan Teknologi Informasi Akuntansi Terhadap Kinerja Individual Pada PT. Bank Pembangunan Daerah Bali Kantor Cabang Singaraja. JIMAT (Jurnal Ilmiah Mahasiswa Akuntansi) Undiksha, 3(1).

Susilawati, C., \& Sunarti, S. (2011). Faktor-Faktor yang Mempengaruhi Pemanfaatan Teknologi Informasi oleh Akuntan. Jurnal Dinamika Akuntansi, 3(2).

Thompson, J. B. (1995). The media and modernity: A social theory of the media. Stanford University Press.

Thompson, R. L., Higgins, C. A., \& Howell, J. M. (1991). Personal computing: toward a conceptual model of utilization. MIS quarterly, 125-143.

Utari, P. S. (2012). Pengaruh Efektivitas Sistem Informasi Akuntansi, Kepercayaan Teknologi Informasi dan Pemanfaatan Teknologi Informasi Terhadap Kinerja Individu Pada Koperasi Simpan Pinjam di Kecamatan Denpasar Selatan. Skripsi Fakultas Ekonomi Universitas Udayana.

Utomo, W. H. (2013). Integration of SME, Industry and Government through Public Infrastructure of SOA and Cloud Computing. Information Technology Journal, 12(4), 594.

Van Dolen, W., De Ruyter, K., \& Lemmink, J. (2004). An empirical assessment of the influence of customer emotions and contact employee performance on encounter and relationship satisfaction. Journal of Business research, 57(4), 437-444. https://doi.org/10.1016/S0148-2963(02)00277-1

Venkatesh, V., \& Davis, F. D. (2000). A theoretical extension of the technology acceptance model: Four longitudinal field studies. Management science, 46(2), 186-204.

Walumbwa, F. O., Mayer, D. M., Wang, P., Wang, H., Workman, K., \& Christensen, A. L. (2011). Linking ethical leadership to employee performance: The roles of leader-member exchange, self-efficacy, and organizational identification. Organizational behavior and human decision processes, 115(2), 204-213. https://doi.org/10.1016/j.obhdp.2010.11.002

Weyai, M. S. (2012). Kesesuaian Tugas dengan Teknologi dan Utilisasi Terhadap Kinerja Karyawan. Tesis Magister Manajemen Program Pasca Sarjana Universitas Kristen Satya Wacana, Salatiga.

Williams, B. K., \& Sawyer, S. C. (2007). Using information technology: A practical introduction to computers \& communications.

Wuryaningrum, A. (2007). Pengaruh teknologi informasi terhadap kinerja individu dengan kepercayaan dan kompleksitas sistem sebagai moderating variable. Skripsi. Malang: Universitas Brawijaya.

Yang, L. R., O'Connor, J. T., \& Wang, C. C. (2006). Technology utilization on different sizes of projects and associated impacts on composite project success. International Journal of Project Management, 24(2), 96-105. https://doi.org/10.1016/j.ijproman.2005.06.008 